\title{
INCIDENCE OF ARMOURED SCALE INSECTS ON PERSIMMONS
}

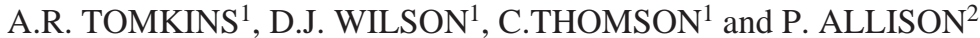 \\ ${ }^{1}$ HortResearch, Ruakura Research Centre, Private Bag 3123, Hamilton \\ ${ }^{2}$ HortResearch, Te Puke Research Centre, Private Bag, Te Puke
}

\begin{abstract}
The incidence of armoured scale insects infesting persimmons (Diospyros kaki) grown in five districts (Whangarei (Northland), Pukekohe (South Auckland), Morrinsville (Waikato), Maketu (Bay of Plenty) and Gisborne (Poverty Bay)) was investigated over three growing seasons (1995/96, 1996/97 and 1997/98). Three species of armoured scale insects were found on persimmon fruit: greedy scale (Hemiberlesia rapax), latania scale (H. lataniae) and oleander scale (Aspidiotus nerii). The species composition differed between districts, with latania scale the most common species recorded overall. Fruit were infested by the first and second generations of all three species. Latania scale infested a higher proportion of leaves than fruit.
\end{abstract}

Keywords: persimmons, Diospyros kaki, armoured scale insects, ecology.

\section{INTRODUCTION}

Persimmons (Diospyros kaki) have been grown as an export crop in New Zealand since the 1980s. The insect and mite pests of persimmons grown in New Zealand include soft and armoured scale insects (Farmer 1952; Prestidge et al. 1989; Steven and Sale 1985). Until recently, these pests have been controlled by following calendar spray programmes. An Integrated Pest Management (IPM) system commonly referred to as Green\&Gold is being introduced (Tomkins et al. 1996). This system involves the replacement of broad-spectrum insecticides with more selective products where available, the introduction of crop monitoring with action thresholds for some pests and improved timing of spray applications. To enable the development of this system, a study was conducted to determine key aspects of the ecology of the persimmon pest fauna. This was required as relatively little was known about the insect and mite pests of persimmon pests in New Zealand. This paper reports on the species of armoured scale insects found on New Zealand persimmons and the timing and levels of crop infestation which can occur in the absence of insecticide applications.

\section{METHODS}

Samples of leaves and fruit were collected from one or two commercial orchards in Pukekohe, Maketu (Bay of Plenty) and Gisborne, and abandoned orchards in Whangarei and Morrinsville. In the first season, only the orchards near Morrinsville, Gisborne (two only in first season) and Pukekohe were sampled. Additional orchards from other fruit-growing districts were included in the second and third seasons. The trees in Maketu, Gisborne and Pukekohe orchards had been treated with a full season export spray programme until the season before sampling began whilst the trees used in Morrinsville and Gisborne orchards had not been sprayed for at least one season previously.

Samples were collected from each orchard at fortnightly intervals from late December until April/May in each of three seasons (1995/96, 1996/97 and 1997/98). At each orchard, either five or ten fruit were sampled from up to 40 trees on each sampling date. The fruit from each tree were placed into labelled plastic bags which were then couriered overnight to HortResearch, Ruakura Research Centre with the 
exception of samples from Morrinsville which were visited to collect samples. Leaf samples were also collected and transported using the same system from the Gisborne orchard during the 1997/98 season. All samples were cool-stored at $4^{\circ} \mathrm{C}$ until microscopically examined to determine infestation by armoured scale insects. Armoured scale insect species, stage of development (instar), whether live or dead, and position on the leaf or fruit (calyx or skin) were recorded.

Data were analysed by ANOVA before and after square root transformation, with a paired T-test used to compare the numbers of latania scale on different parts of trees.

\section{RESULTS AND DISCUSSION}

Three species of armoured scale insects, greedy scale (Hemiberlesia rapax (Comstock)), latania scale (H. lataniae (Signoret)) and oleander scale (Aspidiotus nerii Bouche'), were found infesting persimmon leaves and fruit. Species composition differed between orchards (Table 1). Latania scale was the dominant species on fruit from the Whangarei, Pukekohe and Gisborne orchards, the same regions where latania scale has been commonly found on kiwifruit vines (Berry et al. 1989). In contrast, oleander scale was the most common species on fruit sampled from orchards near Morrinsville and Maketu, although the Maketu results are based on relatively few insects. Oleander scale has also been recorded from kiwifruit vines in the Waikato (Lo and Blank 1989).

The greater prevalence of latania scale in the Whangarei, Pukekohe and Gisborne persimmon orchards is probably also because they were all sheltered by Lombardy poplar (Populus nigra L.) trees which may be heavily infested with latania scale (Hill and Allan 1990). The poplar trees in the orchards in the current study were not sampled but those at Pukekohe and Gisborne were inspected and confirmed to harbour latania scale. The level of fruit infestation by latania scale on persimmon trees in rows at different distances from a poplar shelterbelt in a Gisborne orchard was examined (Fig. 1). By the end of the 1995/96 season in late May, fruit from the row closest to the poplar shelter had a significantly higher $(\mathrm{P}<0.01)$ number of latania scale per fruit (average of 16.4) than those on trees which were seven rows from the shelter (4.1 scale per fruit).

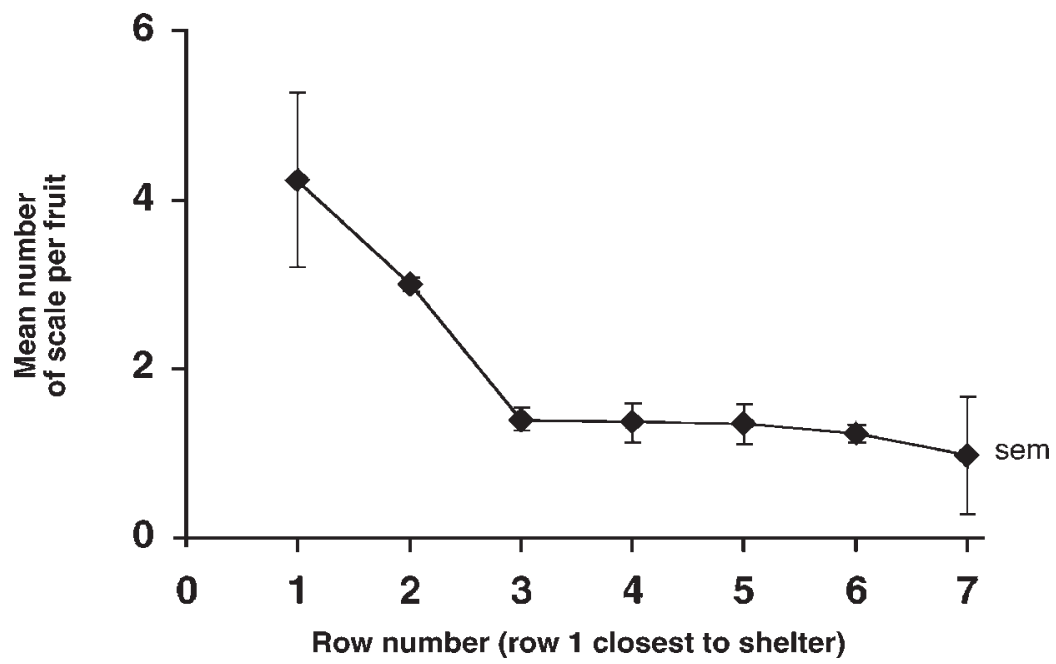

FIGURE 1: Mean number of latania scale per calyx on fruit from persimmon trees in rows at different distances from a poplar shelterbelt in Gisborne during 1995/96. 


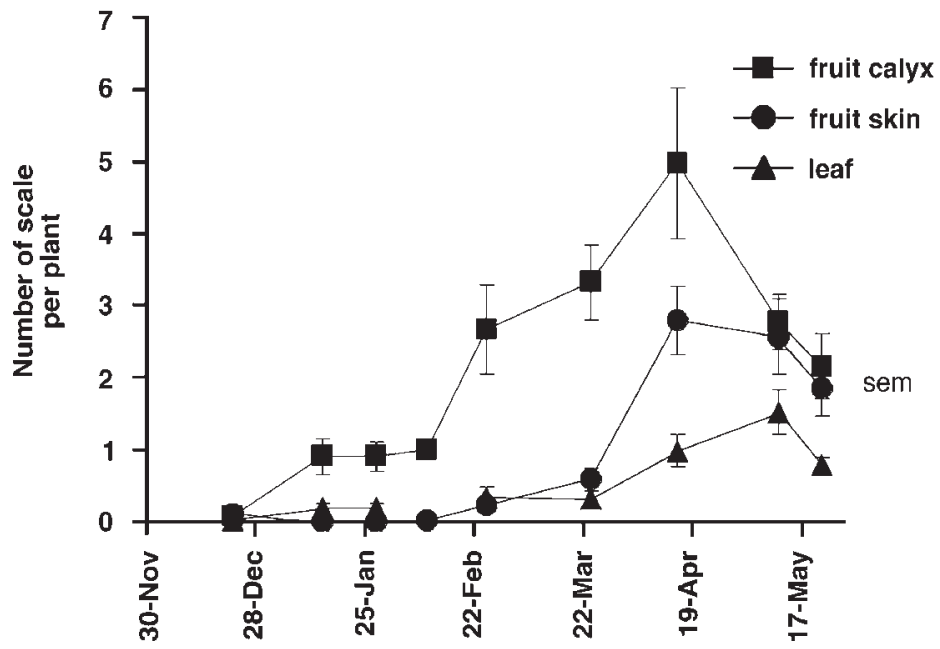

FIGURE 2: Mean number of latania scale per plant part on unsprayed persimmon trees from a Gisborne orchard in 1997/98.

Latania scale were found infesting persimmon leaves and fruit from the start of sampling in late December (Fig. 2) in Gisborne. Both the skin and calyces of fruit were infested by this, and the other two species of armoured scale insects. The level of infestation by latania scale was greater on fruit than on leaves. In the Green\&Gold IPM system, monitoring for armoured scale insects involves fruit inspection. This contrasts with the use of leaves for monitoring in the KiwiGreen system, as the main species of armoured scale insects on kiwifruit (greedy scale) has a similar preference for leaves and fruit (Tomkins et al. 1992). Relatively few latania scale settled on the skin of fruit until mid-February to mid-March, when the level of infestation rose sharply, coinciding with production of crawlers giving rise to the second generation. On the majority of

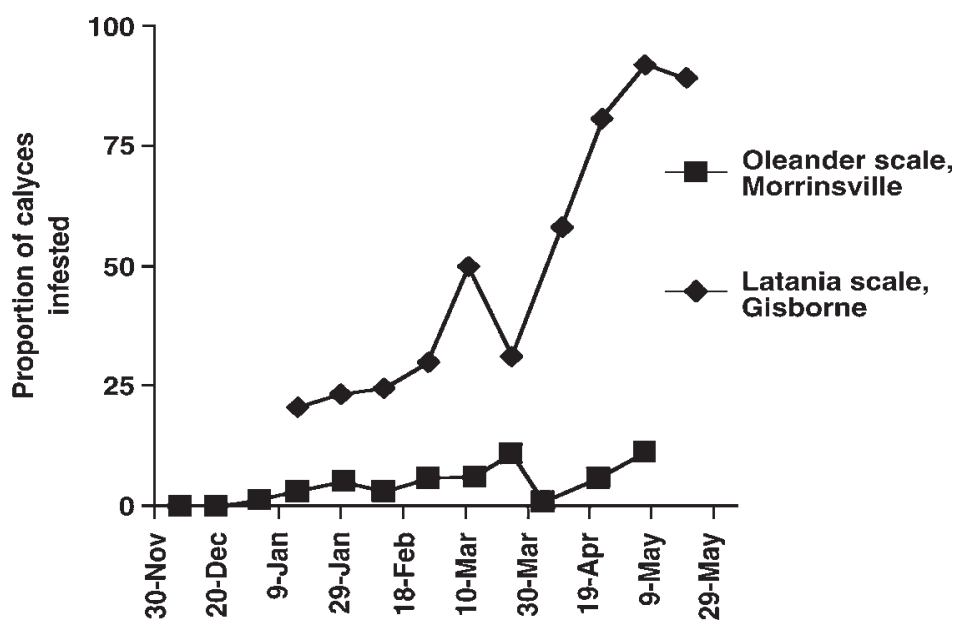

FIGURE 3: Proportion of calyces of persimmon fruit infested by armoured scale insects during 1995/96. 
sampling dates, there was a significantly higher number of latania scale on the calyces than on the skin of fruit.

Oleander scale were found on fruit from early January (Fig. 3), while greedy scale were first found on persimmon fruit in mid-December. For all three armoured scale species, the insects found on fruit before early/mid February were part of the first generation. First generation latania scale have also been observed to settle on apple fruit in the Gisborne area. In contrast, relatively few armoured scale insects belonging to the first generation settle on the fruit of kiwifruit cv. Hayward (Tomkins et al. 1992). This is an important observation because armoured scale insect crawlers often settle near their mother scale. As a result any fruit which are infested by armoured scale insects during the first generation may suffer multiple infestations when the second generation begins. It is therefore very important to achieve good control early in the season before any overwintering armoured scale insects can begin producing crawlers in spring. A threshold based on the previous season's history of crop infestation by armoured scale insects has therefore been incorporated into the Green\&Gold IPM system to ensure effective early control of these pests.

TABLE 1: Total number of armoured scale insects and percent species composition on persimmon fruit in different growing districts.

\begin{tabular}{lccccc}
\hline District & Season & $\begin{array}{c}\text { No. of scale } \\
\text { insects }\end{array}$ & greedy & $\begin{array}{c}\text { \% composition } \\
\text { latania }\end{array}$ & oleander \\
\hline Whangarei & $1996 / 97$ & 265 & 7.2 & 88.3 & 4.5 \\
& $1997 / 98$ & 125 & 0 & 92.8 & 7.2 \\
Morrinsville & $1995 / 96$ & 160 & 0.6 & 1.3 & 98.1 \\
& $1996 / 97$ & 218 & 0 & 0 & 100 \\
& $1997 / 98$ & 80 & 3.8 & 3.8 & 92.4 \\
Pukekohe & $1995 / 96$ & 115 & 7.0 & 93.0 & 0 \\
& $1996 / 97$ & 1050 & 0.9 & 99.1 & 0 \\
Maketu & $1997 / 98$ & 2522 & 0.3 & 99.5 & 0.2 \\
Gisborne & $1997 / 98$ & 29 & 17.2 & 3.4 & 79.3 \\
& $1995 / 96$ & 4352 & 0 & 100 & 0 \\
& $1995 / 96$ & 91 & 0 & 100 & 0 \\
& $1996 / 97$ & 2488 & 0.9 & 99.1 & 0 \\
& $1997 / 98$ & 3312 & 0.1 & 99.9 & 0.0 \\
\hline
\end{tabular}

\section{CONCLUSIONS}

Persimmon fruit may be infested by latania scale, greedy scale or oleander scale belonging to the first and second generations. Control measures against armoured scale insects on persimmons should therefore start when trees are dormant or before flowering to ensure the first generation is controlled. This may require treatment of shelter trees in some orchards, since Lombardy poplar trees, which often used to shelter persimmon orchards, appear to be an important source of latania scale. Monitoring will be necessary from February onwards to determine whether crops are at risk of infestation by armoured scale insects from the second generation, requiring the use of insecticide sprays later in the season.

\section{ACKNOWLEDGEMENTS}

Thanks to Persimmon Industry Council and AGMARDT for funding these studies; to Messrs S. Bent, B. Cooper, P. Coppock, J. Grahame, T. Lupton, G. Tombleson, H. van Leuuwen, L. Wells and B. Wilcox for providing trees and/or collecting samples; to Mr. S. Hutchings for technical assistance and Mr. H. Henderson for statistical analysis. 


\section{REFERENCES}

Berry, J.A., Morales, C.F., Hill, M.G., Lofroth, B.J. and Allan, D.J., 1989. The incidence of three diaspidid scale on kiwifruit in New Zealand. Proc. 42nd N.Z. Weed and Pest Control Conf.: 182-186.

Farmer, A., 1952. Pests and diseases of persimmons in New Zealand and their control. Orchardist of N.Z. 25: 4-9.

Hill, M.G. and Allan, D.J., 1990. Winter clean-up sprays for latania scale (Hemiberlesia lataniae) on lombardy poplar shelter in kiwifruit orchards. Proc. 43 rd N.Z. Weed and Pest Control Conf:: 252-255.

Lo, P.L. and Blank, R.H., 1989. A survey of armoured scale species (Hemiptera: Diaspididae) in kiwifruit orchards. N.Z. Entomol. 12: 1-14.

Prestidge, R.A., Holland, P.T., Clarke, A.D. and Malcolm, C.P., 1989. Pesticides for use close to and during harvest of persimmons. Proc. 42nd N.Z. Weed and Pest Control Conf: : 195-199.

Steven, D. and Sale, P.R., 1985. Insect control trials on persimmons. Proc. 38th N.Z. Weed and Pest Control Conf:: 203-206.

Tomkins, A.R., Thomson, C., Wilson, D.J. and Greaves, A.J., 1992. Armoured scale (Hemiptera: Diaspididae) on unsprayed kiwifruit vines in the Waikato. N.Z. Entomol. 15: 58-63.

Tomkins, A.R., Wilson, D.J., Thomson, C., Allison, P., Spencer, M., Lupton, T., Charles, J., and Allan, D., 1996. A green way to get the gold. Persimmon Profile (April): 12-14. 